\title{
Eye closure and oculopalatal tremor
}

Supplemental data at www.neurology.org

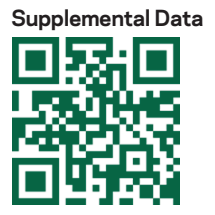

A 59-year-old man with right tectal arteriovenous malformation complicated by brainstem hemorrhage was referred for unusual eye movements. He demonstrated rhythmic movements of face, larynx, and palate with horizontal saccadic intrusions and small amplitude, pendular oscillations of the left eye. Only active eye closure brought out large amplitude globe oscillations (video on the Neurology ${ }^{\circledR}$ Web site at www.neurology.org). Oculopalatal tremor (OPT) is characterized by smooth, aperiodic, low frequency $(1-2 \mathrm{~Hz})$ oscillations of eyes, palate, and occasionally other muscles, ${ }^{1,2}$ and develops after a lesion in the Guillain-Mollaret triangle. ${ }^{1}$ Eye oscillations may be brought out and augmented by active eye closure in establishing diagnosis of OPT.

Jose Luis Lopez, MD, David S. Zee, MD, Baltimore, MD; Leah Levi, MBBS, La Jolla, CA

Author contributions: Dr. Lopez: drafting/revising the manuscript for content, including medical writing for content; administrative, technical, or material support. Dr. Zee: drafting/revising the manuscript for content, including medical writing for content, acquisition of data, study supervision or coordination. Dr. Levi: drafting/revising the manuscript for content, including medical writing for content, acquisition of data, administrative, technical, or material support.

Disclosure: Dr. Lopez reports no disclosures. Dr. Zee serves as an Associate Editor of Frontiers of Neuro-otology and the editorial board of The Cerebellum; Publishing Royalties receives publishing royalties for The Neurology of Eye Movements (Oxford University Press, 2006); and receives research support from the NIH. Dr. Levi reports no disclosures.

Address correspondence and reprint requests to Dr. Jose Luis Lopez, 400 Taylor Boulevard, Suite 301, Pleasant Hill, CA 94523; jllopezMD@gmail.com

1. Shaikh A, Hong S, Liao K, et al. Oculopalatal tremor explained by a model of inferior olivary hypotrophy and cerebellar plasticity. Brain 2010;133:923-940.

2. Jacobs L, Bender MB. Palato-ocular synchrony during eyelid closure. Arch Neurol 1976;33:289-291. 


\section{Neurology}

Eye closure and oculopalatal tremor

Jose Luis Lopez, David S. Zee and Leah Levi

Neurology 2011;77;1929

DOI 10.1212/WNL.0b013e318238eeac

This information is current as of November 21, 2011

\section{Updated Information \&}

Services

Supplementary Material

\section{References}

Subspecialty Collections

Permissions \& Licensing

Reprints including high resolution figures, can be found at: http://n.neurology.org/content/77/21/1929.full

Supplementary material can be found at: http://n.neurology.org/content/suppl/2011/11/21/77.21.1929.DC1

This article cites 2 articles, 0 of which you can access for free at: http://n.neurology.org/content/77/21/1929.full\#ref-list-1

This article, along with others on similar topics, appears in the following collection(s):

All Neuro-ophthalmology

http://n.neurology.org/cgi/collection/all_neuroophthalmology

Arteriovenous malformation

http://n.neurology.org/cgi/collection/arteriovenous_malformation Ocular motility

http://n.neurology.org/cgi/collection/ocular_motility

Tremor

http://n.neurology.org/cgi/collection/tremor

Information about reproducing this article in parts (figures,tables) or in its entirety can be found online at:

http://www.neurology.org/about/about_the_journal\#permissions

Information about ordering reprints can be found online:

http://n.neurology.org/subscribers/advertise

Neurology ${ }^{\circledR}$ is the official journal of the American Academy of Neurology. Published continuously since 1951, it is now a weekly with 48 issues per year. Copyright Copyright $@ 2011$ by AAN Enterprises, Inc.. All rights reserved. Print ISSN: 0028-3878. Online ISSN: 1526-632X.

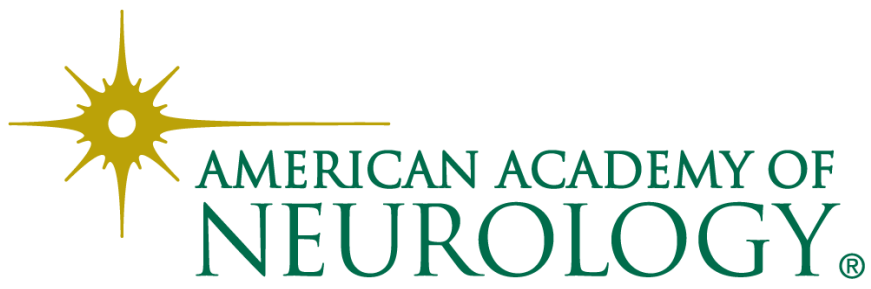

